\title{
Action of defense activator and foliar fungicide on the control of Asiatic rust and on yield and quality of soybean seeds ${ }^{1}$
}

\author{
Bruno Oliveira Carvalho ${ }^{2}$, João Almir Oliveira ${ }^{3}$, Everson Reis Carvalho ${ }^{3}$, \\ Vinícius de Andrade $^{2}$, Thaís Francielle Ferreira ${ }^{3}$, Leandro Vilela Reis ${ }^{3}$
}

\begin{abstract}
The objective of this study was to evaluate the influence of fungicide application (PrioriXtra ${ }^{\circledR}$, azoxystrobin + ciproconazole) and defense activator (Bion ${ }^{\circledR}$, acibenzolar-S-methyl) on the control of Asiatic rust (Phakopsora pachyrhizi), as well as the effect of the disease on the quality of soybean seeds. The experimental design was a randomized block in factorial 4 $\mathrm{X} 10$ with three replications, with four soybean breeding lines, two disease-tolerant and two susceptible and ten managements of rust control, using the products Bion ${ }^{\circledR}$, Priori $X \operatorname{tra}{ }^{\circledR}$ and their combination, applied once, twice and three times, and a control. It evaluated the rate of normalized difference vegetation, productivity, mass of 1000 seeds and seed quality by means of the germination, seedling emergence, accelerated aging and seed health tests. The use of the defense activator alone in the maximum of three applications is not effective in controlling rust. The fungicide used in conjunction or not with the defense activator is effective in controlling rust and improving seed quality, when used with three foliar applications. The defoliation caused by rust affects considerably the formation of seeds, as well as productivity and also the percentage of germination and seedling emergence, and is influenced by genotype.
\end{abstract}

Index terms: acibenzolar-S-methyl, azoxystrobin + ciproconazole, Glycine max, Phakopsora pachyrhizi, physiological potential.

\section{Ação de ativador de defesa e fungicida foliar no controle da ferrugem asiática, na produção e na qualidade das sementes de soja}

\begin{abstract}
RESUMO - Objetivou-se avaliar a aplicação de ativador de defesa (Bion ${ }^{\circledR}$, acibenzolar-S-metil) e fungicida foliar (Priori Xtra ${ }^{\circledR}$, azoxystrobin + ciproconazole) no controle da ferrugem asiática (Phakopsora pachyrhizi) e o efeito da doença sobre a produtividade e a qualidade das sementes de soja. O delineamento foi em blocos casualizados em esquema fatorial 4 X 10 com três repetições, envolvendo quatro linhagens de soja, duas tolerantes e duas suscetíveis à ferrugem e dez manejos de controle, com a utilização de Bion ${ }^{\circledR}$ e Priori Xtra ${ }^{\circledR}$ e a combinação dos mesmos, aplicados uma, duas e três vezes, e uma testemunha. Avaliou-se o índice de vegetação por diferença normalizada, produtividade, massa de mil sementes e qualidade das sementes por meio dos testes de germinação, emergência de plântulas, envelhecimento acelerado e sanidade. A utilização de apenas ativador de defesa no número máximo de três aplicações não é eficiente no controle da ferrugem asiática. O fungicida utilizado em conjunto ou não com o ativador de defesa é eficaz no controle da doença e na melhoria da qualidade das sementes, quando em três aplicações. A desfolha causada pela ferrugem afeta a formação das sementes de soja, a produtividade e as porcentagens de germinação e emergência de plântulas, sendo influenciada pelo genótipo.
\end{abstract}

Termos para indexação: acibenzolar-S-metil, azoxystrobin + ciproconazole, Glycine max, Phakopsora pachyrhizi, potencial fisiológico.

\section{Introduction}

Soybean has contributed decisively to the economic sustainability of the agricultural activity in Brazil. Its cultivation area has expanded year after year, leading the country to the second position in the world ranking of soybean production.
The status of a culture of high relevance in Brazil is due to its importance as a primary source of vegetal oil, animal protein, as well as energy alternatives, such as biofuels production.

The production growth and increased competitiveness of Brazilian soybean have always been linked to scientific advances and availability of technologies to the production

\footnotetext{
${ }^{1}$ Submitted on 07/09/2012. Accepted for publication on 11/06/2012.

${ }^{2}$ Syngenta Seeds Ltda, 38407-049 - Uberlândia, MG, Brasil.

${ }^{3}$ Departamento de Agricultura, Setor de Produção e Tecnologia de Sementes, UFLA, Caixa Postal 3037, 37200-000 - Lavras, MG, Brasil.

*Corresponding author $<$ brunoagroufla@hotmail.com $>$
} 
sector, most of them disseminated by seeds. For this reason, the seeds quality is of vital importance. Crops grown from high vigor seeds tend to have better yields (Kolchinski et al., 2005), an observation confirmed by Scheeren et al. (2010), because both authors observed that yields per area of fields planted with high vigor seeds may be $9 \%$ higher when compared to treatments with low vigor seeds.

One of the main limiting factors to soybean productivity [Glycine $\max (\mathrm{L}$.) Merrill] is related to the occurrence of diseases. Currently, the Asiatic rust, whose etiological agent is the fungus Phakopsora pachyrhizi H. Sydow \& P. Sydow, is one of the most significant diseases because it raises production costs considerably due to the number of fungicides sprays required, which is the only effective control measure (Lima et al., 2010). Soybean Asiatic rust is considered highly aggressive (Juliatti et al., 2005). The rapid expansion and great potential losses caused by the Asiatic rust makes it one of the most critical soybean diseases (Yorinori et al., 2005).

Soybean rust is very aggressive and can limit soybean production even in good weather conditions. The disease can shorten the growth cycle by 25 days, causing the formation of small seeds and reducing yields dramatically. The damages caused by the disease vary from region to region. In the Western Hemisphere, damages range from $30 \%$ to $75 \%$ in the most regions where the plant is cultivated (Zambolim, 2006). According to Yorinori et al. (2005), production losses in Brazil can reach $70 \%$ in non-controlled areas. Soybean plants are susceptible to this fungus in all stages of growth and losses can be as high as 100\% (Kawuki et al., 2003).

Quantified defoliation can be used as a parameter to estimate damages, assess treatments in experiments on soybean diseases control, and to test the genetic materials resistant to the Asiatic rust. To assess disease severity and reduce subjectivity, diagrammatic scales are used (Hirano et al., 2010). However, new technologies have contributed to the assessment of severity of foliar diseases. One of the techniques used to indirectly assess the stress caused by the disease is the determination of the amount of chlorophyll in the leaves by means of reflectance values measured with terrestrial optical sensors. Thus, it is possible to calculate the normalized difference vegetation index (NDVI), which correlates well with the culture parameters, such as yield, foliar $\mathrm{N}$ content, disease severity, and protein in grains (Molin et al., 2010).

Godoy and Henning (2008) studied the effect of seeds treatment and application of foliar fungicides on Asiatic rust and found high correlations between NDVI and disease severity and yield. Hikishima et al. (2010), in a study on damages quantification and the relation between severity, reflectance measures, and yield in the pathosystem of soybean
Asian rust, observed that NDVI data can be used to estimate de damages of the disease and determine the breakeven point, or the threshold of economic loss.

To optimize the control of soybean diseases, crop management measures are necessary to diminish the initial inoculum level and enhance the plants defense, thus preventing the formation of environments conducive to the disease development and facilitating chemical control (Balardin and Madalosso, 2006). Soybean control includes many combined actions to prevent or minimize losses. To date, chemical control with fungicides is the most common and effective control method, because of the rapid progression of the disease. Other control methods are the assessment of resistant cultivars and use of defense activators (Juliatti et al., 2005). The use of fungicides is a guaranteed success in the control of soybean crops, and studies have reported significant yield increases (Dourado Neto et al., 2007; Scherm et al., 2009). Currently, a large variety of fungicides to control Asiatic rust are available in the market. Among them, azoxystrobim + cyproconazole (ProriXtra ${ }^{\circledR}$ ) has shown satisfactory results in many research works (Dourado-Neto et al., 2007; Godoy et al., 2009).

Fungicides, in general, are costly, and in most cases two or more applications are required, thus increasing production costs. Furthermore, the continued use of fungicides with the same active principle can result in the resistance of the pathogen to these products. Therefore, other economically viable strategies to control the disease are necessary, e.g., the development of substances capable of inducing the plants defense system against the pathogens action (Leroux, 1996).

The Systemic Acquired Resistance (SAR) occurs naturally and is an important defense mechanism of the plants against diseases (Moraes, 1998). Regardless of some minor disagreements, researchers have assumed that SAR involves the accumulation of PRPs (Pathogenesis-Related Proteins) as induced plant defense mechanisms. Usually, PRPs accumulate in the plants as a response to infections and resistance activation (Romeiro, 2011). Acibenzolar-S-methyl (ASM), a benzothiadiazol derivative, is considered a resistance activator in many cultures, such as against potato blackleg, caused by the bacterium Pectobacterium carotovorum subsp. atrosepticum (Benelli et al., 2004), and against soybean nematodes and rust (Duarte et al., 2009; Rocha et al., 2000), among other cultures.

In the case of Asiatic rust, there is little knowledge available on their influence on the physiological and health quality of seeds from plants that were treated to control the disease (Gagliardi et al., 2009). Pinto et al. (2011), when working with fungicides to control Asiatic rust, observed that, in favorable climatic conditions for the seeds maturation, high severity of Asiatic rust interferes with productivity but does 
not influence the seeds physiological potential. But Asiatic rust, combined with unfavorable climatic conditions in the final maturation stage, causes the occurrence of greenish seeds, affecting the seeds vigor even after storage. However, these researchers did not use resistance activators (SAR).

Given this context, this study had the objective of assessing the influence of application of defense activator (Bion ${ }^{\circledR}$, acibenzolar-S-methyl) and foliar fungicide (Priori $\mathrm{Xtra}{ }^{\circledR}$, azoxystrobin + ciproconazole) to control Asiatic rust (Phakopsora pachyrhizi), as well their effects and of the disease on the yield and on physiological and health quality of the seeds.

\section{Material and Methods}

The work was carried out in the experimental unit of Syngenta, a company located in the city of Uberlândia, MG, in the Seeds Analysis Laboratory of the Department of Agriculture, and the Seeds Pathology Laboratory of the Department of Phytopathology of the Federal University of Lavras (UFLA), Lavras, MG.

The seeds were planted in direct sowing system (notillage), in Uberlândia, MG, on Feb. 18, 2011. It is worth mentioning that this is not the best and recommended planting time in the year (Embrapa, 2011). We used an experimental vacuum seeder with $0.50 \mathrm{~m}$ spacing between rows and seeding rate of 20 seeds. $\mathrm{m}^{-1}$. The experimental plots consisted of four rows, $5 \mathrm{~m}$ long each, and as useful area it was considered the two central rows, disregarding $0.50 \mathrm{~m}$ at each end. When necessary, supplemental irrigation was provided, identical on all plots. The phitopathogenic agent of Asiatic rust was inoculated on both lateral rows 30 days after sowing by applying a solution with the spores with concentration of 10000 spores. $\mathrm{mL}^{-1}$ and $67 \%$ of feasibility, with the aid of a coastal sprayer and spray volume proportional to 200 L.ha to ensure the presence of the disease.

The statistical design used was randomized blocks, 4 x 10 factorial design, with three replications, using four soybean breeding lines (varieties) and 10 treatments to control the Asiatic rust. Four soybean varieties, two rust resistant (identified as $\mathrm{A}$ and $\mathrm{B})$ and two susceptible to the disease (C and D) were used in the experiment. The 10 control treatments consisted of the use of the products azoxystrobin + cyproconazole (Priori Xtra $\left.{ }^{\circledR}\right)$ and acibenzolar-S-methyl - ASM (Bion $\left.{ }^{\circledR}\right)$ alone, and a combination of both, applied once, twice and three times, and one control receiving only water in three applications (Table 1).

The products were applied in the dosages recommended by the manufacturer, 25 g.ha $^{-1}$ of Bion $₫, 300 \mathrm{~mL} \cdot$ ha $^{-1}$ of Priori Xtra ${ }^{\circledR}$, and $600 \mathrm{~mL} \cdot \mathrm{ha}^{-1}$ of paraffinic mineral oil (Nimbus) was also used (Table 1). The first application was made 40 days after the seedling emergence (stage V5 of plant growth according to Ritchie et al. 1994); after 21 days the second application was made (stage R2), and the third application 21 days after the previous one (stage R5). The applications were made on the two central rows using of a knapsack motor pump, pressure $2.1 \mathrm{kgf.cm}{ }^{-2}$, spray volume of $200 \mathrm{~L} . \mathrm{ha}^{-1}$. During application, a plastic barrier was used to control drift.

Table 1. Description of the treatments used in the experiments to control Asiatic rust.

\begin{tabular}{|c|c|c|c|c|}
\hline Treatment & \multicolumn{2}{|c|}{ Product } & Dose p.c./application & $\mathrm{N}^{\mathrm{o}}$ of applications \\
\hline P1 & Priori $X \operatorname{tra}{ }^{\circledR}$ & Fungicide & 300 mL.ha ${ }^{-1}$ & 1 \\
\hline $\mathrm{P} 2$ & Priori $X \operatorname{tra}{ }^{\circledR}$ & Fungicide & $300 \mathrm{~mL} \cdot \mathrm{ha}^{-1}$ & 2 \\
\hline P3 & Priori Xtra ${ }^{\circledR}$ & Fungicide & $300 \mathrm{~mL} \cdot \mathrm{ha}^{-1}$ & 3 \\
\hline B1 & Bion ${ }^{\circledR}$ & Activator & 25 g.ha ${ }^{-1}$ & 1 \\
\hline B2 & Bion ${ }^{\circledR}$ & Activator & $25 \mathrm{~g} \cdot \mathrm{ha}^{-1}$ & 2 \\
\hline B3 & Bion ${ }^{\circledR}$ & Activator & $25 \mathrm{~g} \cdot \mathrm{ha}^{-1}$ & 3 \\
\hline$(\mathrm{P}+\mathrm{B}) 1$ & Priori $X \operatorname{tra} \AA+$ Bion $\AA$ & Fungicide + Activator & $300 \mathrm{~mL} \cdot \mathrm{ha}^{-1}+25 \mathrm{~g} \cdot \mathrm{ha}^{-1}$ & 1 \\
\hline$(\mathrm{P}+\mathrm{B}) 2$ & Priori $X \operatorname{tra} \AA$ - Bion $\AA$ & Fungicide + Activator & $300 \mathrm{~mL} \cdot \mathrm{ha}^{-1}+25 \mathrm{~g}^{-h^{-1}}$ & 2 \\
\hline$(\mathrm{P}+\mathrm{B}) 3$ & Priori Xtra ${ }^{\circledR}+$ Bion ${ }^{\circledR}$ & Fungicide + Activator & 300 mL.ha ${ }^{-1}+25$ g.ha ${ }^{-1}$ & 3 \\
\hline $\mathrm{T}$ & Water & Control & 0 & 3 \\
\hline
\end{tabular}

During the crop development, specifically at stage R5.4 of plant growth (Ritchie et al. 1994), we used a Green Seeker apparatus to verify the normalized difference vegetation index (NDVI), and readings were taken in 35 points along each row. This was done to indirectly determine the photosynthetic efficiency of the products as a function of the pathogen action on the leaf blade.
Harvest was made manually, as soon as the materials showed ideal moisture for field harvest, and thresh was made by an individual thresher, model TPI, made by Imac. After harvest and thresh, the seeds were weighed and the results were adjusted for $13 \%$ moisture (wet basis), and the results were converted into kilograms per hectare $\left(\mathrm{kg} \cdot \mathrm{ha}^{-1}\right)$. The seeds were then sent to the Seeds Analysis Laboratory and 
Seeds Pathology at UFLA for evaluation of the physical, physiological and health qualities of the seeds through the following testing: weight of thousand seeds, germination, seedling emergence, accelerated aging and vigor, according to the methodologies described below.

Weight of thousand seeds: the sample consisted of eight subsamples of 100 seeds counted manually. Then, the seeds of each replicate were weighted, considering four decimal places. The weight of thousand seeds was calculated according to the Rules for Seed Testing (Brasil, 2009).

Germination test: this test was performed in towel paper moistened with distilled water 2.5 times the dry paper weight. The seeds were placed in a germination chamber at a temperature of $25^{\circ} \mathrm{C}$, and counts were made at the $5^{\text {th }}$ and $8^{\text {th }}$ day after seeding. Evaluations were performed according to the Rules for Seed Testing (Brasil, 2009). Four subsamples of 50 seeds each were used, and the results were expressed in percentage.

Seedling emergence test: four subsamples of 50 seeds each were used. The 50 seeds of each subsample were sown in $60 \mathrm{~cm} \times 40 \mathrm{~cm} \times 10 \mathrm{~cm}$ plastic trays having a substrate of sand + earth in a proportion of $2: 1$, with $70 \%$ of field capacity. The trays with the seeds were placed in a growth chamber adjusted to $25^{\circ} \mathrm{C}$, under alternating light and dark (12 hours). Irrigation was provided whenever needed. The evaluation of normal seedlings was made 14 days after the beginning of the test.

Accelerated aging test: four subsamples of 50 seeds each were placed on an aluminum mesh screen attached to a gerbox. In each gerbox $40 \mathrm{~mL}$ of water were added and maintained in BOD at a temperature of $41^{\circ} \mathrm{C}$ for 48 hours (Marcos-Filho, 1999). After this period, the seeds were submitted to the germination test, according to the procedures described for this test.

Seeds health test: the health test was carried out using the incubation method in paper filter without freezing with four subsamples of 25 seeds per plot in the field, analyzing 300 seeds per treatment. Each subsample was placed on a Petri dish of $15 \mathrm{~cm}$ diameter containing three sheets of paper filter and moistened with a solution of water/agar $1 \%+2.4 \mathrm{D}$ previously sterilized. The seeds were incubated at $20{ }^{\circ} \mathrm{C} \pm 2{ }^{\circ} \mathrm{C}$ inside a chamber with a photoperiod of 12 hours, for seven days (Brasil, 2009). To identify the pathogens present in the seeds, a stereomicroscopy and an optical microscope were used. The incidence was determined in percentage of fungi found.

The data collected were assessed statistically by analysis of variance with 5\% significance level using F-test. To analyze the variance of the percentage of fungi incidence (Health), the data were transformed into $\sqrt{x+1}$. Comparisons of the means were made by the de Scott Knott (1974) test, using the Sisvar software (Ferreira, 2011).

\section{Results and Discussion}

The results of the analysis of variance showed that there was a significant effect for all variables studied for each factor separately, except for the incidence of Fusarium spp. regarding the soybean variety (breeding line) factor (Table 2). In the interaction of factors, there was significance for the results of accelerated aging, yield, vegetation index (NDVI), weight of 1000 seeds, and the rate of seeds infected by Fusarium spp., Cercospora kikuchii e Phomopsis sp.

Table 2. Summary of the analysis of variance of the results of germination (G\%), seedling emergence (E\%), accelerated aging (AE), weight of thousand seeds (W1000), productivity (Prod), normalized difference vegetation index (NDVI), and incidence of Fusarium spp. (Fus), Cercospora kikuchii (Cer) and Phomopsis sp. (Pho) in the seeds, as obtained in the experiment with soybean submitted to different control treatments of Asiatic rust.

\begin{tabular}{ccccccccccc}
\hline \multirow{2}{*}{ FV } & GL & \multicolumn{10}{c}{ Quadratic means } \\
\cline { 3 - 11 } & & G\% & E\% & AE & W1000 & Prod & NDVI & Fus $^{1}$ & Cer $^{1}$ & Pho $^{1}$ \\
\hline Block & 2 & 0.91 & 1.41 & 3.86 & 33.67 & 6536.88 & 0.002 & 0.05 & 0.18 & 0.481 \\
Variety & 3 & $86.05^{*}$ & $66.06^{*}$ & $90.09^{*}$ & $14706.04 *$ & $20269842.0 *$ & $2.520^{*}$ & 0.92 & $29.63^{*}$ & $15.85^{*}$ \\
Treatment & 9 & $30.93^{*}$ & $19.26^{*}$ & $18.15^{*}$ & $1984.83^{*}$ & $1799843.67 *$ & $0.015^{*}$ & $0.88^{*}$ & $2.02^{*}$ & $1.62^{*}$ \\
Lin*Man & 27 & 3.94 & 8.21 & $8.23^{*}$ & $142.35^{*}$ & $128187.93^{*}$ & $0.003^{*}$ & $0.72^{*}$ & $1.54^{*}$ & $0.85^{*}$ \\
Residue & 78 & 4.21 & 5.88 & 3.45 & 61.47 & 7048.61 & 0.001 & 0.41 & 0.72 & 0.54 \\
\hline CV (\%) & 2.24 & 2.57 & 2.03 & 7.11 & 6.04 & 5.27 & 40.59 & 18.67 & 41.78 \\
\hline
\end{tabular}

*Significant at $5 \%$ of probability by F-test $(\mathrm{p} \leq 0.05) .{ }^{1}$ ANOVA with data transformed into $\sqrt{x+1}$.

From the results of germination percentage, as shown in Table 3 (average for the four soybean varieties), all treatments with more than one application, regardless of the product used, showed germination above the control sample, and treatments with PrioriXtra and PrioriXtra + Bion with two or three applications, respectively, showed better results than the others. Better germination rates were observed in the varieties resistant to Asiatic rust (varieties A and $B$ ), and in variety $A$ 
we observe a higher average germination rate when compared to the others (Table 4). For the susceptible varieties, there was no significant difference among the mean values (Table 4). The results found in the present work are different from those reported by Gagliardi et al. (2009), who did not observe effect of the products used in the control of Asiatic rust on the seeds final quality. This is likely related to the intensity of disease in the two fields, as well as the weather conditions, region and type of soils, which are factors that are directly related.

According to the percentage results of seedling emergence, as shown in Table 3, the highest values were observed in the treatments with three applications of PrioriXtra or PrioriXtra + Bion, a result that is similar to that of the germination test. Regarding the other treatments, there was no difference. Table 4 shows that there was a higher percentage of seedling emergence of variety A than the others. For variety $\mathrm{B}$ and varieties that are susceptible to rust (C and D), there was no significant difference with respect to the percentage of seedling emergence.

According to the results of germination and emergence tests, there was a positive effect of the application of fungicide with or without defense activator on the physiological quality of the seeds. It was also found that the number of applications is important to ensure the control of rust and, consequently, to improve the physiological quality of the seeds.

With respect to the accelerated aging test, Table 5, for variety $A$ it was not observed a significant difference between the treatments. However, in general, variety A showed better results than the susceptible cultivars for the treatments assessed. Broadly speaking, the treatments with PrioriXtra ou PrioriXtra + Bion showed better results than the control with Bion only. The number of three applications also had influence on the highest percentage of germination after aging.
The best results of germination and vigor found in the treatments, when compared to the control, allow us to say that there were no phytotoxic effects, once the germination rate of the seeds that received up to three applications was the same of those that received fewer applications, even the control.

Table 3. Mean percentages of seeds germination and seedlings emergence of four varieties of soybean seeds from plants submitted to different treatments to control Asiatic rust.

\begin{tabular}{ccc}
\hline Treatments & Germination $(\%)^{*}$ & $\begin{array}{c}\text { Seedling } \\
\text { emergence }(\%)^{*}\end{array}$ \\
\hline PrioriXtra 1 & $90 \mathrm{c}$ & $93 \mathrm{~b}$ \\
PrioriXtra 2 & $94 \mathrm{a}$ & $95 \mathrm{a}$ \\
PrioriXtra 3 & $92 \mathrm{~b}$ & $97 \mathrm{a}$ \\
Bion 1 & $89 \mathrm{~d}$ & $93 \mathrm{~b}$ \\
Bion 2 & $92 \mathrm{~b}$ & $94 \mathrm{~b}$ \\
Bion 3 & $92 \mathrm{~b}$ & $94 \mathrm{~b}$ \\
(PrioriXtra + Bion) 1 & $91 \mathrm{c}$ & $94 \mathrm{~b}$ \\
(PrioriXtra + Bion) 2 & $92 \mathrm{~b}$ & $93 \mathrm{~b}$ \\
(PrioriXtra + Bion) 3 & $94 \mathrm{a}$ & $95 \mathrm{a}$ \\
Control & $91 \mathrm{c}$ & $94 \mathrm{~b}$ \\
\hline
\end{tabular}

*Means followed by the same letter do not differ among themselves by the Scott-Knott test at $5 \%$ probability.

Table 4. Mean percentages of seeds germination and seedlings emergence of four soybean seeds varieties.

\begin{tabular}{ccc}
\hline Variety & Germination (\%)* & Seedling emergence (\%)* \\
\hline A & $94 \mathrm{a}$ & $96 \mathrm{a}$ \\
$\mathrm{B}$ & $92 \mathrm{~b}$ & $94 \mathrm{~b}$ \\
$\mathrm{C}$ & $90 \mathrm{c}$ & $93 \mathrm{~b}$ \\
$\mathrm{D}$ & $91 \mathrm{c}$ & $94 \mathrm{~b}$ \\
\hline
\end{tabular}

*Means followed by the same letter do not differ among themselves by the Scott-Knott test at $5 \%$ probability.

Table 5. Mean percentage of germination of soybean seeds submitted to accelerated aging test and weight of 1000 seeds test of four soybean varieties submitted to different treatments for the control of Asiatic rust.

\begin{tabular}{|c|c|c|c|c|c|c|c|c|}
\hline \multirow{3}{*}{ Treatment } & \multicolumn{4}{|c|}{ Accelerated aging $(\%)$} & \multicolumn{4}{|c|}{ Weight of 1000 seeds $(\mathrm{g})$} \\
\hline & \multicolumn{4}{|c|}{ Varieties } & \multicolumn{4}{|c|}{ Varieties } \\
\hline & $\mathrm{A}$ & B & $\mathrm{C}$ & $\mathrm{D}$ & $\mathrm{A}$ & B & $\mathrm{C}$ & $\mathrm{D}$ \\
\hline 1 & $94 \mathrm{Aa}$ & $95 \mathrm{Aa}$ & $92 \mathrm{Ba}$ & $91 \mathrm{Bb}$ & $117.07 \mathrm{Bc}$ & $144.97 \mathrm{Aa}$ & $89.50 \mathrm{Ca}$ & $93.53 \mathrm{Cb}$ \\
\hline $\mathrm{P} 2$ & $93 \mathrm{Aa}$ & $94 \mathrm{Aa}$ & $90 \mathrm{Ba}$ & $91 \mathrm{Bb}$ & $137.97 \mathrm{Ab}$ & $132.40 \mathrm{Ab}$ & $99.97 \mathrm{Ba}$ & $95.27 \mathrm{Bb}$ \\
\hline P3 & $95 \mathrm{Aa}$ & $94 \mathrm{Aa}$ & $90 \mathrm{Ba}$ & $94 \mathrm{Aa}$ & $154.73 \mathrm{Aa}$ & $151.73 \mathrm{Aa}$ & $103.40 \mathrm{Ba}$ & $105.87 \mathrm{Ba}$ \\
\hline $\mathrm{B} 1$ & $93 \mathrm{Aa}$ & $92 \mathrm{Ab}$ & $87 \mathrm{Bb}$ & $90 \mathrm{Ab}$ & 109.83 Ac & $111.57 \mathrm{Ac}$ & $81.20 \mathrm{Bb}$ & $84.03 \mathrm{Bb}$ \\
\hline B2 & $95 \mathrm{Aa}$ & $91 \mathrm{Bb}$ & $89 \mathrm{Ba}$ & $89 \mathrm{Bb}$ & 109.17 Ac & $114.53 \mathrm{Ac}$ & $78.13 \mathrm{Bb}$ & $86.13 \mathrm{Bb}$ \\
\hline B3 & $94 \mathrm{Aa}$ & $92 \mathrm{Ab}$ & $89 \mathrm{Ba}$ & $90 \mathrm{Bb}$ & $122.43 \mathrm{Ac}$ & $114.93 \mathrm{Ac}$ & $78.90 \mathrm{Bb}$ & $81.90 \mathrm{Bb}$ \\
\hline$(\mathrm{P}+\mathrm{B}) 1$ & $91 \mathrm{Aa}$ & $91 \mathrm{Ab}$ & $91 \mathrm{Aa}$ & $93 \mathrm{Aa}$ & 119.93 Ac & $117.50 \mathrm{Ac}$ & $89.73 \mathrm{Ba}$ & $90.57 \mathrm{Bb}$ \\
\hline$(\mathrm{P}+\mathrm{B}) 2$ & $94 \mathrm{Aa}$ & $91 \mathrm{Ab}$ & $91 \mathrm{Aa}$ & $91 \mathrm{Ab}$ & $143.90 \mathrm{Ab}$ & $151.27 \mathrm{Aa}$ & $94.90 \mathrm{Ba}$ & $97.77 \mathrm{Bb}$ \\
\hline$(\mathrm{P}+\mathrm{B}) 3$ & $93 \mathrm{Aa}$ & $92 \mathrm{Bb}$ & $89 \mathrm{Ba}$ & $96 \mathrm{Aa}$ & $152.50 \mathrm{Aa}$ & $151.80 \mathrm{Aa}$ & $96.27 \mathrm{Ca}$ & $111.40 \mathrm{Ba}$ \\
\hline $\mathrm{T}$ & $93 \mathrm{Aa}$ & $90 \mathrm{Bb}$ & $84 \mathrm{Cb}$ & $89 \mathrm{Bb}$ & $115.73 \mathrm{Ac}$ & $113.20 \mathrm{Ac}$ & $77.83 \mathrm{Bb}$ & $86.93 \mathrm{Bb}$ \\
\hline
\end{tabular}

Means followed by letters in uppercase in the rows and lowercase in the columns do not differ among themselves by the Scott-Knott test at $5 \%$ probability. 
From Table 5, one can see that the disease stress affected significantly the weight of thousand seeds of all varieties, because the rust-resistant varieties had a higher average weight of thousand seeds than the others. Likewise, the application of PrioriXtra ou PrioriXtra + Bion in a number of three applications had better control of the rust, resulting in a weight of thousand seeds higher than the other treatments and the control.

According to Carvalho and Nakagawa (2000), seeds that are larger or with higher density are those that usually have well-formed embryos and a greater amount of reserves, being those that potentially have more vigor, a fact that was observed by Pádua et al. (2010). This corroborates the results found for rust-resistant varieties in view of their higher average weight of thousand seeds and best results in the germination and seedlings emergence tests when compared to the susceptible varieties.

According to the yield figures presented in Table 6, it was found that the resistant varieties have higher average yields than the susceptible ones. Variety A showed the highest average yield among the varieties studied. For the diseaseresistant varieties, treatment with three applications of PrioriXtra + Bion resulted in the highest average yields among the treatments. For the susceptible varieties, in addition to the treatment with PrioriXtra + Bion, two or three applications of PrioriXtra alone also had higher yields.

Table 6. Mean yields (kg.ha-1) and normalized difference vegetation index (NDVI) of four soybean varieties submitted to different treatments of Asiatic rust control.

\begin{tabular}{|c|c|c|c|c|c|c|c|c|}
\hline \multirow{3}{*}{ Treatment } & \multicolumn{4}{|c|}{ Yield (kg.ha ${ }^{-1}$ ) } & \multicolumn{4}{|c|}{ NDVI } \\
\hline & \multicolumn{4}{|c|}{ Varieties } & \multicolumn{4}{|c|}{ Varieties } \\
\hline & A & B & $\mathrm{C}$ & D & A & B & $\mathrm{C}$ & $\mathrm{D}$ \\
\hline P1 & $2478.0 \mathrm{Ad}$ & $1691.7 \mathrm{Bc}$ & $798.2 \mathrm{Cb}$ & $813.8 \mathrm{Cb}$ & $0.7717 \mathrm{Ab}$ & $0.7503 \mathrm{Aa}$ & $0.2429 \mathrm{Bb}$ & $0.2321 \mathrm{Ba}$ \\
\hline P2 & $2545.1 \mathrm{Ad}$ & $1706.9 \mathrm{Bc}$ & $923.1 \mathrm{Ca}$ & $967.0 \mathrm{Ca}$ & $0.8011 \mathrm{Aa}$ & $0.7446 \mathrm{Ba}$ & $0.2604 \mathrm{Cb}$ & $0.2408 \mathrm{Ca}$ \\
\hline P3 & $2787.2 \mathrm{Ac}$ & $2146.2 \mathrm{Bb}$ & $1004.0 \mathrm{Ca}$ & $999.5 \mathrm{Ca}$ & $0.8140 \mathrm{Aa}$ & $0.7741 \mathrm{Aa}$ & $0.2964 \mathrm{Ba}$ & $0.2384 \mathrm{Ca}$ \\
\hline B1 & 1709.2 Af & $1149.8 \mathrm{Be}$ & $439.3 \mathrm{Cc}$ & $525.1 \mathrm{Cd}$ & $0.7572 \mathrm{Ab}$ & $0.7057 \mathrm{Bb}$ & $0.2435 \mathrm{Cb}$ & $0.2228 \mathrm{Ca}$ \\
\hline B2 & 1722.8 Af & $1337.6 \mathrm{Bd}$ & $479.7 \mathrm{Cc}$ & $466.7 \mathrm{Cd}$ & $0.7439 \mathrm{Ab}$ & $0.6610 \mathrm{Bb}$ & $0.2668 \mathrm{Ca}$ & $0.2178 \mathrm{Da}$ \\
\hline B3 & 1938.6 Ae & $1160.9 \mathrm{Be}$ & $491.6 \mathrm{Cc}$ & $428.7 \mathrm{Cd}$ & $0.7558 \mathrm{Ab}$ & $0.6924 \mathrm{Bb}$ & $0.2565 \mathrm{Cb}$ & $0.2358 \mathrm{Ca}$ \\
\hline$(\mathrm{P}+\mathrm{B}) 1$ & $2528.2 \mathrm{Ad}$ & $2172.5 \mathrm{Bb}$ & $844.9 \mathrm{Cb}$ & 656.3 Dc & $0.7722 \mathrm{Ab}$ & $0.7423 \mathrm{Aa}$ & $0.2858 \mathrm{Ba}$ & $0.2355 \mathrm{Ca}$ \\
\hline$(\mathrm{P}+\mathrm{B}) 2$ & $3086.6 \mathrm{Ab}$ & $2200.6 \mathrm{Bb}$ & $740.8 \mathrm{Db}$ & $1031.4 \mathrm{Ca}$ & $0.8328 \mathrm{Aa}$ & $0.7672 \mathrm{Ba}$ & $0.2821 \mathrm{Ca}$ & $0.2448 \mathrm{Ca}$ \\
\hline$(\mathrm{P}+\mathrm{B}) 3$ & $3426.2 \mathrm{Aa}$ & $2374.0 \mathrm{Ba}$ & $1070.3 \mathrm{Ca}$ & $1048.6 \mathrm{Ca}$ & $0.8238 \mathrm{Aa}$ & $0.7531 \mathrm{Ba}$ & $0.2941 \mathrm{Ca}$ & $0.2328 \mathrm{Da}$ \\
\hline $\mathrm{T}$ & $1830.8 \mathrm{Ae}$ & $1195.9 \mathrm{Be}$ & $326.5 \mathrm{Cd}$ & $393.1 \mathrm{Cd}$ & $0.7423 \mathrm{Ab}$ & $0.5083 \mathrm{Bc}$ & $0.2040 \mathrm{Cc}$ & $0.2016 \mathrm{Ca}$ \\
\hline
\end{tabular}

Means followed by letters in uppercase in the rows and lowercase in the columns do not differ among themselves by the Scott-Knott test at $5 \%$ probability

The yields shown in the experiment (Table 6) are below those usually observed in trials with soybean and the national averages in the last years, which were 3,115 in 2010/11 and 2,665 kg.ha ${ }^{-1}$ in 2011/12 (Conab, 2012). Despite the supplemental irrigation, the low yields are directly related to the sowing time of the experiment, outside the recommended period, because in the region it should be made before mid October and not later than the first half of December, depending on the local conditions and cultivars, with best results for crops seeded in the second half of October and in November (Embrapa, 2011). The relation between late soybean sowing and yield loss was found by Peluzio et al. (2010), Meotti et al. (2012) and also by Freitas et al. (2010), whose research was also conducted in Uberlândia, MG, thus demonstrating the importance of appropriate sowng time to obtain high soybean yields.

The utilization of PrioriXtra ou PrioriXtra + Bion in a number of three applications provided an efficient control of rust, because it ensured better seeds formation in addition to higher final yields (Table 6). According to Hoffmann et al. (2004), a significant effect of the application of fungicides in the control of final cycle diseases on soybean yields can be easily obtained. Similar results were also found by the Mato Grosso Foundation (2001), whose experiments showed that the greater the number of applications the better the control of diseases, resulting in an increased yield and weight of 100 seeds.

From the results obtained for normalized difference vegetation index (NDVI) (Table 6), it could be observed the superior values found in the resistant varieties. Such results can be correlated with yield and the severity of the disease by means of injuries in the leaf blade and, consequently, reduction of the leaves photosynthetic efficiency. The results obtained with the use of Green Seeker apparatus to measure the plants photosynthetic efficiency corroborate the results reported by Godoy and Henning (2008), who found correlations between the evaluation of NDVI with disease severity and final yields.

According to the health test, the presence of three species of fungi was found in the seeds under study, namely Fusarium spp., Phomopsis sp. and Cercospora kikuchii (Table 7). With 
respect to the fungus Fusarium spp., it was not found the same behavior as observed in the other variables, which showed better performances of the resistant varieties and when the products were applied twice or three times. These factors had not influenced the presence of fungus Fusarium spp., and the highest incidences occurred with seeds of varieties A and C, which did not receive any application of the products, as well as variety $\mathrm{C}$, which was sprayed with three applications of PrioriXtra, showing that these products are not efficient in controlling this fungus. It can also be noted that the resistance of the varieties to rust is not associated with the incidence of Fusarium spp., once variety D, which is susceptible to rust, was the one that in general showed the lowest rates of occurrence of Fusarium spp. (Table 7).

Table 7. Mean percentages of seeds with incidence of Fusarium spp., Cercospora kikuchii and Phomopsis sp. of soybean varieties submitted to different treatments to control Asiatic rust.

\begin{tabular}{|c|c|c|c|c|c|c|c|c|c|c|c|c|}
\hline \multirow{3}{*}{ Treatment } & \multicolumn{4}{|c|}{ Fusarium spp. (\%) } & \multicolumn{4}{|c|}{ Cercospora kikuchii (\%) } & \multicolumn{4}{|c|}{ Phomopsis spp. (\%) } \\
\hline & \multicolumn{4}{|c|}{ Varieties } & \multicolumn{4}{|c|}{ Varieties } & \multicolumn{4}{|c|}{ Varieties } \\
\hline & A & $\mathrm{B}$ & $\mathrm{C}$ & $\mathrm{D}$ & A & $\mathrm{B}$ & $\mathrm{C}$ & $\mathrm{D}$ & A & B & $\mathrm{C}$ & $\mathrm{D}$ \\
\hline P1 & $2 \mathrm{Ab}$ & $2 \mathrm{Aa}$ & $1 \mathrm{Ab}$ & $0 \mathrm{Aa}$ & $10 \mathrm{Bb}$ & $11 \mathrm{Bb}$ & $31 \mathrm{Ab}$ & $17 \mathrm{Ba}$ & $2 \mathrm{Ba}$ & $0 \mathrm{Ba}$ & $9 \mathrm{Aa}$ & $2 \mathrm{Bb}$ \\
\hline $\mathrm{P} 2$ & $2 \mathrm{Ab}$ & $1 \mathrm{Aa}$ & $4 \mathrm{Aa}$ & $2 \mathrm{Aa}$ & $16 \mathrm{Ab}$ & $17 \mathrm{Ab}$ & $27 \mathrm{Ab}$ & $16 \mathrm{Aa}$ & $0 \mathrm{Aa}$ & $0 \mathrm{Aa}$ & $1 \mathrm{Ab}$ & $4 \mathrm{Ab}$ \\
\hline P3 & $1 \mathrm{Bb}$ & $2 \mathrm{Ba}$ & $6 \mathrm{Aa}$ & $0 \mathrm{Ba}$ & $27 \mathrm{Aa}$ & $25 \mathrm{Aa}$ & $33 \mathrm{Ab}$ & $15 \mathrm{Aa}$ & $0 \mathrm{Ba}$ & $0 \mathrm{Ba}$ & $2 \mathrm{Bb}$ & $8 \mathrm{Aa}$ \\
\hline B1 & $3 \mathrm{Ab}$ & $1 \mathrm{Aa}$ & $2 \mathrm{Ab}$ & $0 \mathrm{Aa}$ & $13 \mathrm{Bb}$ & $13 \mathrm{Bb}$ & $42 \mathrm{Aa}$ & $11 \mathrm{Ba}$ & $1 \mathrm{Ba}$ & $0 \mathrm{Ba}$ & $3 \mathrm{Bb}$ & $13 \mathrm{Aa}$ \\
\hline B2 & $2 \mathrm{Ab}$ & $1 \mathrm{Aa}$ & $1 \mathrm{Ab}$ & $0 \mathrm{Aa}$ & $23 \mathrm{Ba}$ & $19 \mathrm{Ba}$ & $44 \mathrm{Aa}$ & $13 \mathrm{Ba}$ & $0 \mathrm{Ba}$ & $0 \mathrm{Ba}$ & $3 \mathrm{Ab}$ & $6 \mathrm{Ab}$ \\
\hline B3 & $3 \mathrm{Ab}$ & $3 \mathrm{Aa}$ & $1 \mathrm{Ab}$ & $0 \mathrm{Aa}$ & $7 \mathrm{Bb}$ & $11 \mathrm{Bb}$ & $39 \mathrm{Aa}$ & $14 \mathrm{Ba}$ & $0 \mathrm{Ba}$ & $1 \mathrm{Ba}$ & $4 \mathrm{Ab}$ & $5 \mathrm{Ab}$ \\
\hline$(\mathrm{P}+\mathrm{B}) 1$ & $1 \mathrm{Ab}$ & $5 \mathrm{Aa}$ & $0 \mathrm{Ab}$ & $4 \mathrm{Aa}$ & $10 \mathrm{Bb}$ & $21 \mathrm{Aa}$ & $30 \mathrm{Ab}$ & $13 \mathrm{Ba}$ & $0 \mathrm{Ba}$ & $0 \mathrm{Ba}$ & $7 \mathrm{Aa}$ & $5 \mathrm{Ab}$ \\
\hline$(\mathrm{P}+\mathrm{B}) 2$ & $1 \mathrm{Ab}$ & $1 \mathrm{Aa}$ & $0 \mathrm{Ab}$ & $3 \mathrm{Aa}$ & $20 \mathrm{Ba}$ & $30 \mathrm{Aa}$ & $43 \mathrm{Aa}$ & $17 \mathrm{Ba}$ & $0 \mathrm{Aa}$ & $0 \mathrm{Aa}$ & $1 \mathrm{Ab}$ & $1 \mathrm{Ab}$ \\
\hline$(\mathrm{P}+\mathrm{B}) 3$ & $1 \mathrm{Ab}$ & $5 \mathrm{Aa}$ & $1 \mathrm{Ab}$ & $1 \mathrm{Aa}$ & $33 \mathrm{Aa}$ & $13 \mathrm{Bb}$ & $29 \mathrm{Ab}$ & $20 \mathrm{Ba}$ & $0 \mathrm{Ba}$ & $1 \mathrm{Ba}$ & $13 \mathrm{Aa}$ & $3 \mathrm{Bb}$ \\
\hline $\mathrm{T}$ & $11 \mathrm{Aa}$ & $1 \mathrm{Ba}$ & $6 \mathrm{Aa}$ & $1 \mathrm{Ba}$ & $8 \mathrm{Cb}$ & $9 \mathrm{Cb}$ & $45 \mathrm{Aa}$ & $21 \mathrm{Ba}$ & $5 \mathrm{Ba}$ & $0 \mathrm{Ba}$ & $15 \mathrm{Aa}$ & $11 \mathrm{Aa}$ \\
\hline
\end{tabular}

Means followed by letters in uppercase in the rows and lowercase in the columns do not differ among themselves by the Scott-Knott test at $5 \%$ probability. The original mean values were presented, but the data were compared according to the transformed data (Transformation into $\sqrt{x+1}$ ).

Incidence of Cercospora kikuchii in the seeds occurred in higher percentages than the other fungi (Table 7). Regarding variety $\mathrm{D}$, there was no significant difference among the treatments evaluated. Conversely, for variety $\mathrm{C}$, there was a higher incidence of the fungus in the treatments with Bion only and for the control. Among the resistant cultivars, it was found a higher percentage of seeds with incidence of the fungus in the treatments with PrioriXtra with three applications, Bion and PrioriXtra + Bion with two applications, proving that these products are not efficient nor are indicated to control this fungus (Table 7).

Regarding Phomopsis sp., in general it was observed a higher incidence percentage in rust-susceptible seed cultivars (Table 7). But regarding variety $\mathrm{A}$ and $\mathrm{B}$ there was no significant difference between the treatments, and the incidence was significantly lower when compared to the susceptible varieties, regardless of the product and number of applications. Such lower incidence can be explained by the better physical and physiological quality of the seeds provided by the resistant varieties, because this disease hinders the development of the seeds by reducing the leaf area, and the seeds become more susceptible to the fungus Phomopsis sp. that infects the seeds at the final cycle of the culture, causing reduced germination and less vigor.

\section{Conclusions}

Using only defense activator (acibenzolar-S-metil, ASM) in a maximum of three applications is not effective to control soybean Asiatic rust.

The use of fungicide azoxystrobin + ciproconazole in conjunction or not with defense activator (acibenzolar-Smetil, ASM) is efficient in controlling the Asiatic rust and improving the soybean seeds quality when used in three foliar applications.

The defoliation caused by rust affects considerably the seeds formation, as well as the seeds yield and the percentage of germination and seedling emergence, and is also influenced by the genotype.

\section{Acknowledgements}

Our thanks to the CNPq, CAPES, and FAPEMIG for the financial support.

\section{References}

BALARDIN, R.S.; MADALOSSO, M.G. Fatores que afetam a eficiência na 
aplicação de fungicidas. In: BORGES, L.D. (Ed.). Tecnologia de aplicação de defensivos agricolas. Passo Fundo: UEPF, 2006. p.63-67.

BENELLI, A.I.H.; DENARDIM, N.D.; FORCELINI, C.A. Ação do Acibenzolar-S-Metil aplicado em tubérculos e plantas de batata contra canela preta, incitada por Pectobacterium carotovorum subsp. atrosepticum. Fitopatologia Brasileira, v.29, n.3, p.263-267, 2004. http://www.scielo.br/ $\mathrm{pdf} / \mathrm{fb} / \mathrm{v} 29 \mathrm{n} 3 / 20359 . \mathrm{pdf}$

BRASIL. Ministério da Agricultura, Pecuária e Abastecimento. Regras para análise de sementes. Ministério da Agricultura, Pecuária e Abastecimento. Secretaria de Defesa Agropecuária. Brasília: MAPA/ACS, 2009. 395p. http://www.agricultura.gov.br/arq editor/file/laborat $\%$ c3\%b3rio/sementes/ regras $\% 20$ para $\% 20$ analise $\% 20 \mathrm{de} \% 20$ sementes.pdf

CARVALHO, N.M.; NAKAGAWA, J. Sementes: ciência, tecnologia e produção. 4.ed. Jaboticabal: FUNEP, 2000. 588p.

COMPANHIA NACIONAL DE ABASTECIMENTO - CONAB. Acompanhamento da safra brasileira: grãos, oitavo levantamento, maio/2012. http://www.conab.gov.br/conteudos.php? $\mathrm{a}=1253 \& \mathrm{t}=2$. Accessed on: Oct. $22^{\text {th }} 2012$.

DOURADO-NETO, D.; DARIO, G.J.A.; MARTIN, T.N.; BONNECARRÈRE, R.A.G.; MANFRON, P.A.; VIEIRA JÚNIOR, P.A. Controle químico da ferrugem asiática na cultura da soja em condições de campo. Revista da FZVA, v.14, n.1, p.69-80, 2007. http://revistaseletronicas. pucrs.br/ojs/index.php/fzva/article/viewFile/2479/1938

DUARTE, H.S.S.; ZAMBOLIMI, L.; RODRIGUES, F.A.; RIOS, J.A.; LOPES, U.P. Silicato de potássio, acibenzolar-S-metil e fungicidas no controle da ferrugem da soja. Ciência Rural, v.39, n.8, p.2271-2277, 2009. http://www.scielo.br/pdf/cr/v39n8/a329cr1463.pdf

EMPRESA BRASILEIRA DE PESQUISA AGROPECUÁRIA - EMBRAPA. Tecnologias de produção de soja: região central do Brasil 2012 e 2013. Londrina, 2011. 262 p. (Sistemas de produção, 15).

FERREIRA, D.F. Sisvar: a computer statistical analysis system. Ciência e Agrotecnologia, v.35, n.6, p.1039-1042, 2011. http://www.scielo.br/pdf/ cagro/v35n6/a01v35n6.pdf

FUNDAÇÃO MATO GROSSO. Boletim de pesquisa de soja. Rondonópolis, 2001. 144p. (Boletim, 5).

FREITAS, M.C.M.; HAMAWAKI, O.T.; BUENO, M.R.; MARQUES, M. C. Época de semeadura e densidade populacional de linhagens de soja UFU de ciclo semitardio. Bioscience Journal, v.26, n.5, p.698-708, 2010. http://www. seer.ufu.br/index.php/biosciencejournal/article/view/7203/5258

GAGLIARDI, B; CARVALHO, T.C.; PUPIM, T.L.; GOMES-JUNIOR, F.G., TIMÓTEO, T.S.; KOBORI, N.N.; MORAES, M.H.D.; MENTEN, J.O.M. Efeito de fungicidas para controle da ferrugem asiática na qualidade de sementes de soja. Revista Brasileira de Sementes, v.31, n.4, p.120-125, 2009. http://www.scielo.br/pdf/rbs/v31n4/14.pdf

GODOY, C.V.; FLAUSINO, A.M.; SANTOS, L.C.M.; DEL PONTE, E.M. Eficiência do controle da ferrugem asiática da soja em função do momento de aplicação sob condições de epidemia em Londrina, PR. Tropical Plant Pathology, v.34, n.1, p.56-61, 2009. http://www.scielo.br/pdf/tpp/v34n1/a11v34n1.pdf

GODOY, C.V.; HENNING, A.A. Tratamento de semente e aplicação foliar de fungicidas para o controle da ferrugem-da-soja. Pesquisa Agropecuária Brasileira, v.43, n.10, p.1297-1302, 2008. http://www.scielo.br/pdf/pab/v43n10/06.pdf

HIKISHIMA, M.; CANTERI, M.G.; GODOY, C.V.; KOGA, L.J.; SILVA, A.J. Quantificação de danos e relações entre severidade, medidas de refletância e produtividade no patossistema ferrugem asiática da soja. Tropical Plant Pathology, v.35, n.2, p.96-103, 2010. http://www.scielo.br/ $\mathrm{pdf} / \mathrm{tpp} / \mathrm{v} 35 \mathrm{n} 2 / \mathrm{v} 35 \mathrm{n} 2 \mathrm{a} 04 . \mathrm{pdf}$

HIRANO, M.; HIKISHIMA, M.; SILVA, A.J.; XAVIER, S.A.; CANTERI, M.G. Validação de escala diagramática para estimativa de desfolha provocada pela ferrugem asiática em soja. Summa Phytopathologica, v.36, n.3, p.248250, 2010. http://www.scielo.br/pdf/sp/v36n3/v36n3a12.pdf

HOFFMANN, L.L.; REIS, E.M.; FORCELINI, C.A.; PANISSON, E.; MENDES, C.S.; CASA, R.T. Efeito da rotação de cultura, de cultivares e da aplicação de fungicida sobre o rendimento de grãos e doenças foliares em soja. Fitopatologia Brasileira, v.29, n.3, p.245-251, 2004. http://www.scielo. $\mathrm{br} / \mathrm{pdf} / \mathrm{fb} / \mathrm{v} 29 \mathrm{n} 3 / 20356 . \mathrm{pdf}$

JULIATTI, F.C.; POLIZEL，A.C.; BALARDIN，R.S.; VALE，F.X.R Ferrugem da soja: epidemiologia e manejo para uma doença reemergente. Revisão Anual de Patologia de Plantas, v.13, p.351-395, 2005.

KAWUKI, R.S.; ADIPALA, E.; TUKAMUHABWA, P. Yield loss associated with soya bean rust (Phakopsora pachyrhizi Syd.) in Uganda. Journal of Phythopatology, v.151, n.1, p.7-12, 2003. http://onlinelibrary.wiley.com/ doi/10.1046/j.1439-0434.2003.00668.x/pdf

KOLCHINSKI, E.M.; SCHUCH, L.O.B.; PESKE, S.T. Vigor de sementes e competição intra-específica em soja. Ciência Rural, v.35, n.6, p.1248-1256, 2005. http://www.scielo.br/pdf/cr/v35n6/a04v35n6.pdf

LEROUX, P. Recent developments in the mode of action of fungicides. Pesticide Science, v.47, n.2, p.191-197, 1996. http://onlinelibrary.wiley.com/doi/10.1002/ (sici)1096-9063(199606)47:2\%3c191::aid-ps415\%3e3.0.co;2-i/pdf

LIMA, L.M.; POZZA, E.A.; POZZA, A.A.A.; FONSECA, T.A.P.; CARVALHO, J.G. Quantificação da ferrugem asiática e aspectos nutricionais de soja suprida com silício em solução nutritiva. Summa Phytopathologica, v.36, n.1, p.51-56, 2010. http://www.scielo.br/pdf/sp/v36n1/09.pdf

MARCOS-FILHO, J. Teste de envelhecimento acelerado. In KRZYZANOWSKI, F.C.; VIEIRA, R.D.; FRANCA-NETO, J.B. (Ed.). Vigor de sementes: conceitos e testes. Londrina: ABRATES, 1999. p.324-332.

MEOTTI, G.V.; BENIN, G.; SILVA, R.R.; BECHE, E.; MUNARO, L.B. Épocas de semeadura e desempenho agronômico de cultivares de soja Pesquisa Agropecuária Brasileira, v.47, n.1, p.14-21, 2012. http://www. scielo.br/pdf/pab/v47n1/47n01a03.pdf

MOLIN, J.P.; FRASSON, F.R.; AMARAL, L.R.; POVH, F.P.; SALVI, J.V. Capacidade de um sensor ótico em quantificar a resposta da cana de açúcar a doses de nitrogênio. Revista Brasileira de Engenharia Agrícola e Ambiental, v.14, n.12, p.1345-1349, 2010. http://www.scielo.br/pdf/rbeaa/v14n12/14.pdf

MORAES, M.G. Mecanismos da resistência sistêmica adquirida em plantas. Revisão Anual de Patologia de Plantas, v.6, p.261-284, 1998.

PÁDUA, G.P.; ZITO, R.K.; ARANTES, N.E.; FRANÇA-NETO, J.B Influência do tamanho da semente na qualidade fisiológica e na produtividade da cultura da soja. Revista Brasileira de Sementes, v.32, n.3, p.09-16, 2010. http://www.scielo.br/pdf/rbs/v32n3/v32n3a01.pdf

PELUZIO, J.M.; VAZ-DE-MELO, A.V; COLOMBO, G.A.; SILVA, R.R.; AFFÉRRI, F.S.; PIRES, L.P.M.; BARROS, H.B. Efeito da época e densidade de semeadura na produtividade de grãos de soja na Região Centro-Sul do estado do Tocantins. Pesquisa Aplicada \& Agrotecnologia, v.3, n.3, p.145-153, 2010. http://revistas.unicentro.br/index.php/repaa/article/download/798/1250

PINTO, T.L.F., CICERO, S.M., FRANÇA-NETO, J.B., DOURADO-NETO, D., FORTI, V.A. Fungicidas foliares e a doença ferrugem asiática na produção 
e na qualidade de sementes de soja. Revista Brasileira de Sementes, v.33, n.4, p.680-688, 2011. http://www.scielo.br/pdf/rbs/v33n4/10.pdf

RITCHIE, S.W.; HANWAY, J.J.; THOMPSON, C.E.; BENSON, G.O. How a soybean plant develops. Ames: Iowa State University of Science and Technology: Cooperative extension, service, 1994. 20p. (Special Report, 53).

ROCHA, M.R.; CASTRO, R.M.; PINA, R.C.; MARTINI, A.L. Efeito do acibenzolar-s-methyl (benzothiadiazole), como indutor de resistência sistêmica em soja (Glycine max cv. FT-Cristalina), sobre Heterodera glycines. Pesquisa Agropecuária Tropical, v.30, n.2, p.35-38, 2000. http:// www.revistas.ufg.br/index.php/pat/article/view/2758/2768

ROMEIRO, R.S. Indução de resistência em plantas a patógenos. Viçosa, MG: UFV, 2011. http://www.ufv.br/dfp/bac/indures.pdf. Accessed on: Nov. 27 2011.

SCHEEREN, B.R.; PESKE, S.T.; SCHUCH, L.O.B.; BARROS, A.C.A. Qualidade fisiológica e produtividade de sementes de soja. Revista Brasileira de Sementes, v.32, n.3, p.35-41, 2010. http://www.scielo.br/pdf/rbs/v32n3/v32n3a04.pdf
SCHERM, H.; CHRISTIANO, R.S.C.; ESKER, P.D.; DEL PONTE, E.M.; GODOY, C.V. Quantitative review of fungicide efficacy trials for managing soybean rust in Brazil. Crop Protection, v.28, n.9, p.774-782, 2009. http:// www.sciencedirect.com/science/article/pii/S0261219409001227

SCOTT, A.J.; KNOTT, M. A cluster analysis method for grouping means in the analysis of variance. Biometrics, v.30, p.507-512, 1974. http://www. biometrics.tibs.org/

YORINORI, J.T.; PAIVA, W.M.; FREDERICK, R.D.; COSTAMILAN, L.M.; BERTAGNOLLI, P.F.; HARTMAN, G.L.; GODOY, C.V.; NUNESJUNIOR, J. Epidemics of soybean rust (Phakopsora pachyrhizi) in Brazil and Paraguay from 2001 to 2003. Plant Disease, v.89, n.6, p.675-677, 2005. http://apsjournals.apsnet.org/doi/pdf/10.1094/PD-89-0675

ZAMBOLIM, L. Ferrugem asiática da soja. Viçosa, MG: UFV, 2006. 140p. 